\title{
Transforming Growth Factor- $\alpha$ Null and Senescent Mice Show Decreased Neural Progenitor Cell Proliferation in the Forebrain Subependyma
}

\author{
Vincent Tropepe, Constance G. Craig, Cindi M. Morshead, and Derek van der Kooy \\ Neurobiology Research Group, Department of Anatomy and Cell Biology, University of Toronto, Toronto, \\ Ontario M5S 1A8, Canada
}

The adult mammalian forebrain subependyma contains neural stem cells and their progeny, the constitutively proliferating progenitor cells. Using bromodeoxyuridine labeling to detect mitotically active cells, we demonstrate that the endogenous expression of transforming growth factor- $\alpha$ (TGF $\alpha$ ) is necessary for the full proliferation of progenitor cells localized to the dorsolateral corner of the subependyma and the full production of the neuronal progenitors that migrate to the olfactory bulbs. Proliferation of these progenitor cells also is diminished with age (in 23- to 25-months-old compared with 2- to 4-months-old mice), likely because of a lengthening of the cell cycle. Senescence or the absence of endogenous TGF $\alpha$ does not affect the numbers of neural stem cells isolated in vitro in the presence of epidermal growth factor. These results suggest that endogenous TGF $\alpha$ and the effects of senescence may regulate the proliferation of progenitor cells in the adult subependyma, but that the number of neural stem cells is maintained throughout life.

Key words: subependyma; olfactory bulb; progenitor cell; stem cell; proliferation; transforming growth factor- $\alpha$; senescence
The extent of the embryonic germinal zone is gradually reduced in the perinatal mammalian forebrain, giving rise in adults to an ependymal monolayer lining the lateral ventricles and to a two- to three-cell-layer-thick subependyma (Privat and Leblond, 1972; Takahashi et al., 1996a,b). Subependymal cells isolated from the adult mouse brain retain the capacity to differentiate into neurons or glia in vitro (Lois and Alvarez-Buylla, 1993), whereas in vivo these cells exhibit the ability to migrate and differentiate into interneurons within the olfactory bulb (Altman, 1969; Lois and Alvarez-Buylla, 1994). Other studies also demonstrate the in vitro isolation of neural stem cells from the adult forebrain (Reynolds and Weiss, 1992; Gritti et al., 1996), stem cells similar to those that are the precursors to the progenitor cell lineages in the embryonic forebrain (Reynolds et al., 1992; Davis and Temple, 1994). These stem cells exhibit the fundamental stem cell properties of long-term self-renewal and multipotentiality (Potten and Loeffler, 1990; Reynolds and Weiss, 1996).

The lineage relationship between stem and progenitor cells in vivo has been clarified recently. Two subpopulations of the proliferating precursor cells in the adult subependyma have been characterized: constitutively proliferating progenitor cells with a cell cycle time of $\sim 12.5 \mathrm{hr}$ (Morshead and van der Kooy, 1992) and their precursors, the relatively quiescent stem cells with a longer cell cycle time of up to $28 \mathrm{~d}$ (Morshead et al., 1994). One of the progeny of each constitutively proliferating progenitor cell division will undergo cell death or migrate and differentiate into

Received May 14, 1997; revised July 23, 1997; accepted August 5, 1997.

This work was supported by the Medical Research Council of Canada and the Canadian Neuroscience Network. We thank Esther Galindo for excellent technical assistance.

Correspondence should be addressed to Vincent Tropepe, Neurobiology Research Group, Department of Anatomy and Cell Biology, University of Toronto, Medical Sciences Building Room 1105, 1 King's College Circle, Toronto, Ontario M5S 1A8, Canada.

Copyright (C) 1997 Society for Neuroscience $0270-6474 / 97 / 177850-10 \$ 05.00 / 0$ neurons within the olfactory bulb, thus maintaining a steady-state mode of cell division without expanding the population (Morshead and van der Kooy, 1992; Lois and Alvarez-Buylla, 1994).

The endogenous factors that regulate the proliferation of neural stem and progenitor cells in the adult subependyma are poorly understood. Two candidates for the endogenous regulation of cell proliferation are epidermal growth factor (EGF) and transforming growth factor- $\alpha$ (TGF $\alpha)$. TGF $\alpha$ mRNA has been localized to the adult striatum and olfactory bulbs, both of which are in close apposition to the forebrain subependyma (Wilcox and Derynck, 1988; Seroogy et al., 1993). Conversely, EGF mRNA is localized to relatively ventrocaudal forebrain regions in the adult, such as the globus pallidus, with apparently little expression near the subependyma (Fallon et al., 1984; Seroogy et al., 1995). EGFreceptor expression is detected in both the early postnatal ventricular zone and the adult subependymal compartments (Morshead et al., 1994; Seroogy et al., 1994, 1995; Craig et al., 1996), suggesting that cells in these regions are competent to respond to $\mathrm{EGF}$ and TGF $\alpha$. Intraventricular infusions of either EGF or TGF $\alpha$ in the adult brain can modulate the in vivo proliferation of subependymal precursor cells by inducing divisions of stem and progenitor cells (Craig et al., 1996). Thus, on the basis of endogenous expression patterns and the exogenous ability to modulate proliferation, these studies indicate that TGF $\alpha$ is the best candidate for endogenously regulating the proliferation of this adult precursor population.

By using mice with a TGF $\alpha$-targeted null mutation (Luetteke et al., 1993; Mann et al., 1993), we were able to test directly the role of endogenous TGF $\alpha$ in regulating the in vivo proliferation of the constitutively proliferating progenitor cells in the adult subependyma and the in vitro clonal proliferation of neural stem cells. The same experimental approach also enabled us to test whether the proliferation of subependymal neural stem and progenitor cells decreases with age. 


\section{MATERIALS AND METHODS}

Animals. Male $\mathrm{TGF} \alpha^{(-)}$mice generated on the $\mathrm{B} 6,129 / \mathrm{F} 2$ genetic background (STOCK-Tgfa $<$ Tmlr $>$ ) and STOCK controls were obtained from Jackson Laboratory (Bar Harbor, ME). Male senescent (23-25 months old) mice and young adult controls (2-4 months old) maintained on the SW/COBS genetic background were obtained from the National Institute of Aging.

Bromodeoxyuridine (BrdU) labeling and detection. Mice were injected with BrdU (Sigma, St. Louis, MO) $(120 \mathrm{mg} / \mathrm{kg}$, i.p., dissolved in $0.007 \mathrm{~N}$ $\mathrm{NaOH}$ in $0.9 \% \mathrm{NaCl}$ ) every $2 \mathrm{hr}$ for $10 \mathrm{hr}$ and killed $0.5 \mathrm{hr}$ after the last injection. Animals were killed and brains were processed for immunohistochemistry as described below. Rat monoclonal anti-BrdU (1:100; Seralab, London, UK) (primary antibody) and biotinylated-donkey antirat (1:200; Jackson ImmunoResearch, West Grove, PA) (secondary antibody) with streptavidin-Texas Red or streptavidin-CY3 (1:100; Sigma) were used for BrdU detection.

Immunohistochemistry. Animals were killed by anesthetic overdose and perfused transcardially with $4 \%$ paraformaldehyde and $0.4 \%$ picric acid in $0.16 \mathrm{M}$ phosphate buffer, $\mathrm{pH} 6.9$ (Zamboni and de Martino, 1967). Brains were post-fixed in the perfusing solution for $90 \mathrm{~min}$ at $4^{\circ} \mathrm{C}$ and then cryoprotected for at least $24 \mathrm{hr}$ in $10 \%$ sucrose in $0.1 \mathrm{M}$ PBS, pH 7.2 . Serial $14 \mu \mathrm{m}$ coronal cryosections $\left(-19^{\circ} \mathrm{C}\right)$ of mouse forebrain were mounted directly onto gelatin-coated slides. After initial treatment with $1 \mathrm{M} \mathrm{HCl}$ for $30 \mathrm{~min}$ at $65^{\circ} \mathrm{C}$ to denature cellular DNA, sections were washed three times (10 min each) with washing solution (10 mM PBS) Sections were incubated for $24 \mathrm{hr}\left(4^{\circ} \mathrm{C}\right)$ in primary antibody diluted in washing solution containing $0.3 \%$ Triton $\mathrm{X}-100$ and $0.01 \%$ sodium azide After incubation in the primary antibody, sections were washed (as above) and incubated with the biotinylated secondary antibody for $2 \mathrm{hr}$ at $37^{\circ} \mathrm{C}$ followed by incubation with tertiary streptavidin-Texas Red or streptavidin-CY3 for $40 \mathrm{~min}$ at $37^{\circ} \mathrm{C}$. Sections were washed three times (5 min each), coverslipped with Immu-mount (Shandon-Lipshaw, Pittsburgh, PA), and examined under a fluorescent microscope (Nikon). Specificity of immunostaining was confirmed by the absence of detectable fluorescence in sections processed after omitting the primary antibody.

Nissl staining. Cell density counts were ascertained by taking three to four coronal sections (that were evenly spaced throughout the counted area) per brain from three to four mice per experimental group and their appropriate controls and staining for Nissl substance using cresyl violet. The numbers of cells per unit area were counted from sampled areas in the medial wall, lateral wall, and dorsolateral corner of the adult subependyma. These same sections were also used for camera lucida (Nikon) drawings to determine the area of the subependyma from the same sampled, evenly spaced sections.

Brain dissection and isolation of neurospheres in vitro. The protocol used to generate neurospheres in vitro was adopted from Reynolds and Weiss (1992). Briefly, mice were killed via cervical dislocation, and their brains were excised under sterile conditions. Medial and lateral portions of the lateral ventricle subependyma were dissected from both hemispheres, pooled together, and subsequently cut into $1 \mathrm{~mm}^{2}$ fragments in oxygenated artificial cerebrospinal fluid (aCSF) that contained $124 \mathrm{~mm}$ $\mathrm{NaCl}, 5 \mathrm{~mm} \mathrm{KCl}, 1.3 \mathrm{~mm} \mathrm{MgCl}_{2}, 2 \mathrm{mM} \mathrm{CaCl}_{2}, 26 \mathrm{mM} \mathrm{NaHCO}_{3}$, and 10 $\mathrm{mM}$ D-glucose. The tissue from each brain was transferred to a spinner flask (Bellco Glass) containing aCSF (as above), but modified to contain high $\mathrm{Mg}^{2+}\left(3.2 \mathrm{~mm} \mathrm{MgCl}_{2}\right)$ and low $\mathrm{Ca}^{2+}\left(0.1 \mathrm{mM} \mathrm{CaCl}_{2}\right)$ concentrations, and containing $1.33 \mathrm{mg} / \mathrm{ml}$ trypsin (Sigma), $0.67 \mathrm{mg} / \mathrm{ml}$ hyaluronidase (Sigma), and $0.2 \mathrm{mg} / \mathrm{ml} \mathrm{kynurenic} \mathrm{acid} \mathrm{(Sigma)} \mathrm{to} \mathrm{dissociate} \mathrm{tissue,}$ and oxygenated at $30^{\circ} \mathrm{C}$ for $90 \mathrm{~min}$. Tissue was then transferred to serum-free media containing $0.7 \mathrm{mg} / \mathrm{ml}$ trypsin inhibitor (Boehringer Mannheim, Indianapolis, IN) and triturated with a fire-polished Pasteur pipette. Cells were cultured in chemically defined serum-free media containing DMEM/F12 (1:1) (Life Technologies, Gaithersburg, MD), 5 mM HEPES buffer, $0.6 \%$ glucose, $3 \mathrm{~mm} \mathrm{NaHCO}, 2$ mm glutamine, 25 $\mu \mathrm{g} / \mathrm{ml}$ insulin, $100 \mu \mathrm{g} / \mathrm{ml}$ transferrin, $20 \mathrm{nM}$ progesterone, $60 \mu \mathrm{M} \mathrm{pu}-$ trescine, and $30 \mathrm{~nm}$ sodium selenite in the presence of EGF $(20 \mathrm{ng} / \mathrm{ml}$; purified from mouse submaxillary gland; Upstate Biotechnology, Lake Placid, NY) in 35-mm-diameter Nunclon culture dishes. After 12-14 d in vitro, the numbers of spheres generated in the culture wells $(12$ wells/ subependyma) were counted, and the total number of spheres per subependyma was averaged over the number of brains. Data were collected from three independent mouse culture preparations in each group of each experiment.

Olfactory bulb cell counts. Mice were injected intraperitoneally (as described previously) every $2 \mathrm{hr}$ for five injections. The animals were maintained on a $12 \mathrm{hr}$ light/dark cycle with food and water ad libitum and were allowed to survive for $31 \mathrm{~d}$. The animals were then killed and the tissue was processed for immunocytochemistry as described above. Sampled, evenly spaced sections through the olfactory bulb (starting from the rostral tip of a defined subependymal layer within the center of the internal granule layer and terminating caudally at the appearance of the accessory olfactory nuclei) were included in the analyses.

Estimating a change in cell cycle time. Animals received one intraperitoneal injection $(0.15 \mathrm{ml})$ of BrdU (Sigma) $(18 \mathrm{mg} / \mathrm{ml}$ dissolved in $0.007 \mathrm{~N} \mathrm{NaOH})$ at time designated $t=0$. At $12.5 \mathrm{hr}(t=12.5)$ after the initial BrdU injection, mice received one intraperitoneal injection $(0.15$ $\mathrm{ml}$ ) of tritiated thymidine ( ${ }^{3} \mathrm{H}$-thy; specific activity $\left.50 \mathrm{Ci} / \mathrm{mM}\right)$. Animals were killed $1 \mathrm{hr}$ after the last injection with an anesthetic overdose. The mice were then transcardially perfused with fixative (as above), and the brains were removed and post-fixed in perfusing solution for $90 \mathrm{~min}$ at $4^{\circ} \mathrm{C}$ followed by cryoprotection in $10 \%$ sucrose at $4^{\circ} \mathrm{C}$ for at least $24 \mathrm{hr}$. Forebrain coronal cryosections were cut at $6 \mu \mathrm{m}$, mounted on gelatincoated slides, and processed for $\mathrm{BrdU}$ and ${ }^{3} \mathrm{H}$-thy as follows. Sections were incubated in $1.0 \mathrm{M} \mathrm{HCl}$ at $65^{\circ} \mathrm{C}$ for $30 \mathrm{~min}$ and subsequently washed in a buffer (10 mM PBS) three times (10 min each). Sections were then incubated in 1:100 anti-BrdU (Sera-Lab, Sussex, UK) (diluted in wash buffer) for $24 \mathrm{hr}$ at $4^{\circ} \mathrm{C}$. Sections were then washed three times $(10 \mathrm{~min}$ each) and incubated in biotinylated donkey anti-rat antibody (Jackson Laboratory) at 1:100 dilution (in wash buffer) for $1 \mathrm{hr}$ at room temperature. After sections were washed, bound biotinylated secondary antibody was detected using avidin-bound peroxidase $(10 \mu \mathrm{l} / \mathrm{ml}$; Vector Kit, Vector Laboratories, Burlingame, CA) at room temperature for $30 \mathrm{~min}$, washed, and incubated with diaminobenzidine $(1 \mathrm{mg} / \mathrm{ml}$; Vector Kit) for 2-10 min at room temperature in the dark. Subsequently, sections were defatted in xylene and dehydrated in increasing concentrations of alcohol and processed for autoradiography by dipping the slides in liquid emulsion (Kodak NTB-2 nuclear track emulsion). The sections were exposed for 7 weeks, after which time they were developed with Kodak D-19 developer. The total numbers of $\mathrm{BrdU}^{+}$cells within the entire extent of the subependyma, and within the dorsolateral corner subregion alone, were counted in sections caudal to the genu of the corpus callosum and rostral to the crossing of the anterior commissure. The numbers of $\mathrm{BrdU}^{+} \beta{ }^{\beta} \mathrm{H}$-thy ${ }^{+}$cells were also counted within the same sections. The average numbers of double-labeled cells as percentages of the total numbers of cells proliferating at $t=0$ were calculated.

Cell counts. For all histological forebrain and olfactory bulb sections, cell numbers were estimated by quantifying the number of cell profiles/ section at constant intervals and correcting for nuclear size and section thickness to obtain an unbiased number of cell profiles (Abercrombie, 1946). In light of the concerns regarding the use of assumption-based methods to accurately represent cell number (Coggeshall and Lekan, 1996), we analyzed our olfactory bulb migration data set for senescent mice by comparing the assumption-based method and the optical disector method to determine whether the final estimates of cell number were significantly different. There were no significant differences in our estimates of cell number comparing the Abercrombie and optical disector methods in either the 2- to 4-months-old $\left(t_{6}=0.55 ; p>0.05\right)$ or 23 - to 25 -months-old $\left(t_{6}=0.34 ; p>0.05\right)$ groups. Therefore, we refer to our unbiased estimates of cell profiles as cell numbers. The estimates of $\mathrm{BrdU}^{+}$cell numbers (within the anatomical region of the olfactory bulb defined above) that were larger in the 2- to 4-months-old mice than in the 23- to 25-months-old mice showed similar significant differences using the Abercrombie $\left(t_{6}=5.09 ; p<0.05\right)$ and optical disector $\left(t_{6}=6.44 ; p<\right.$ $0.05)$ methods.

\section{RESULTS}

\section{Division of constitutively proliferating progenitor cells is attenuated throughout the subependyma in senescent mice, but only attenuated in the dorsolateral corner in TGF $\alpha^{(-/-)}$mice}

Constitutively proliferating progenitor cells are present throughout the entire forebrain subependymal region. The rostral, dorsolateral corner of the subependyma may be enriched for neuronal progenitor cells that migrate to the olfactory bulbs where they undergo differentiation (Altman, 1969; Luskin, 1993; Lois and Alvarez-Buylla, 1994). The localization of olfactory bulb neuronal progenitors to the dorsolateral corner of the lateral ventricle suggests that this region of the subependyma may be functionally 

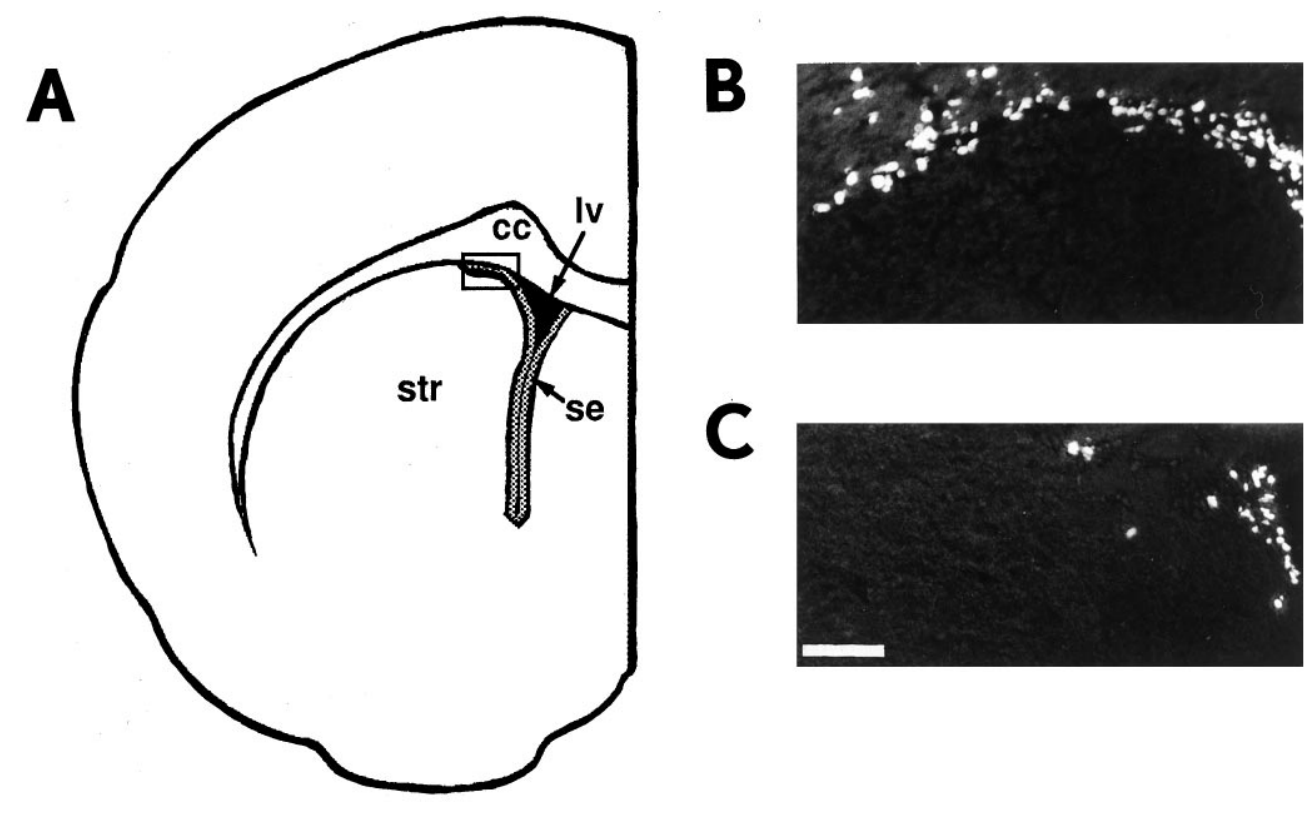

Figure 1. Decreased subependymal cell proliferation in $\mathrm{TGF} \alpha^{(--)}$mice in vivo. $A$, Schematic diagram representing a coronal section through the adult mouse forebrain lateral ventricle subependyma ( gray shaded area around $l v$ ). Boxed area indicates the region of the dorsolateral corner pictured in $B$ and $C$. $B, C$, Fluorescent photomicrograph of a coronal section through the dorsolateral corner of the subependyma of the adult forebrain lateral ventricle in $(B)$ a control B6129/F2 mouse and $(C)$ a $\mathrm{TGF} \alpha^{(-1-)}$ mouse. Animals received 10 $\mathrm{hr}$ of BrdU injections to label the entire constitutively proliferating population. $c c$, Corpus callosum; $l v$, lateral ventricle; se, subependyma; str, striatum. Scale bar, $80 \mu \mathrm{m}$.

distinct from the remaining nondorsolateral subependyma. To determine the role of TGF $\alpha$ and the effects of senescence on the proliferation of constitutively proliferating progenitor cells in vivo, we analyzed progenitor cell proliferation separately in the dorsolateral corner and in the remaining nondorsolateral subependyma. This analysis allowed us to test whether cells in distinct regions of the subependyma are differentially affected by $\mathrm{TGF} \alpha^{(-1-)}$ or senescence. We used BrdU, a thymidine analog incorporated into the DNA of these cells in the S-phase of their cell cycle (Nowakowski et al., 1989), to quantify cell proliferation of these cells in adult TGF $\alpha^{(-1-)}$ and senescent mice (Fig. 1).

Attenuated proliferation of constitutively proliferating progenitor cells in the dorsolateral corner of the adult subependyma was observed in TGF $\alpha^{(-/-)}$(Fig. 2A) and senescent mice (Fig. 2B). The numbers of $\mathrm{BrdU}^{+}$constitutively proliferating progenitor cells were significantly decreased by $43 \%$ in $\mathrm{TGF}^{(-1-)}\left(t_{6}=6.8\right.$; $p<0.05)$ and by $47 \%$ in senescent $\left(t_{6}=6.6 ; p<0.05\right)$ mice when compared with their control groups. To compare the effects of TGF $\alpha$ deficiency on the proliferation of the remaining population of constitutively proliferating progenitor cells, we quantified the number of $\mathrm{BrdU}^{+}$cells localized to the remaining nondorsolateral subependyma. The numbers of $\mathrm{BrdU}^{+}$cells in the nondorsolateral subependyma of adult $\mathrm{TGF} \alpha^{(-/-)}$mice were not significantly different from their strain-matched controls $\left(t_{6}=1.4 ; p>\right.$ $0.05)$ and suggest that these cells proliferate independently of normal endogenous TGF $\alpha$ expression (Fig. $2 C$ ). Senescent mice (Fig. 2D), however, had $64 \%$ fewer constitutively proliferating progenitor cells throughout the nondorsolateral subependyma than their appropriate controls $\left(t_{8}=10.8 ; p<0.05\right)$.

To examine the possibility that the differences observed in the quantified numbers of $\mathrm{BrdU}^{+}$cells were caused by other histological changes, coronal forebrain sections from both groups and their appropriate controls were stained for Nissl substance using cresyl violet to determine the density of subependymal cells. The cellular density per unit area in the dorsolateral corner of the subependyma was not significantly altered in $\mathrm{TGF} \alpha^{(-/-)}\left(t_{6}=\right.$ $0.82 ; p>0.05)$ or senescent $\left(t_{4}=2.54 ; p>0.05\right)$ mice compared with their controls. Similarly, no differences in cell density were observed in the lateral and medial walls of the subependyma for these two experimental groups compared with their appropriate controls. These same sections were also used for camera lucida tracings to determine whether there were any changes in the area of the subependyma. No changes in the entire area of the forebrain subependyma were observed in the $\mathrm{TGF} \alpha^{(-/-)}\left(t_{6}=1.81 ; p>\right.$ $0.05)$ and senescent $\left(t_{4}=0.18 ; p>0.05\right)$ mice compared with their controls. Thus, the decrease in the numbers of $\mathrm{BrdU}^{+}$cells is likely the result of reduced proliferation. In both experimental (mutant vs old) groups and their appropriate control groups we observed baseline differences in proliferation attributable to mouse strain (B6,129/F2 vs SW/COBS). These differences were consistent across all experiments throughout the results. Background strain differences may correspond to variations in endogenous levels of some factor(s) involved in regulating the proliferation of the constitutively proliferating progenitor cell population.

\section{The numbers of subependymal neuronal progenitor cells that have migrated to the olfactory bulbs are decreased in TGF $\alpha^{(-/-)}$and senescent mice}

To determine whether the decreased numbers of $\mathrm{BrdU}^{+}$cells in the dorsolateral corner of the subependyma in $\mathrm{TGF} \alpha^{(-)-}$and senescent mice are also reflected in an attenuation in the numbers of neuronal progenitor cells that have migrated to the olfactory bulbs, animals were injected with BrdU and allowed to survive for $31 \mathrm{~d}$ after injection, a sufficient time to allow for the migration of labeled neuronal progenitor cells to the olfactory bulbs (Lois and Alvarez-Buylla, 1994; Doetsch and Alvarez-Buylla, 1996). The numbers of $\mathrm{BrdU}^{+}$cells within the olfactory bulbs were then assayed. The total number of $\mathrm{BrdU}^{+}$olfactory bulb cells was significantly decreased by $37 \%$ in $\mathrm{TGF} \alpha^{(-/-)}$mice and by $70 \%$ in senescent mice when compared with their appropriate control groups (Fig. 3). There were significantly fewer numbers of $\mathrm{BrdU}^{+}$ cells in TGF $\alpha^{(-/-)}\left(t_{8}=3.40 ; p<0.05\right)$ and senescent $\left(t_{6}=5.09\right.$; $p<0.05)$ mice compared with strain-matched controls. The data indicate that the absence of endogenous TGF $\alpha$ in the adult forebrain and the effects of senescence cause a decrease in the proliferation of neuronal progenitors that have migrated rostrally from primarily the dorsolateral corner of the subependyma to the olfactory bulbs. Furthermore, the significantly greater percentage 


\section{Dorsolateral Corner}

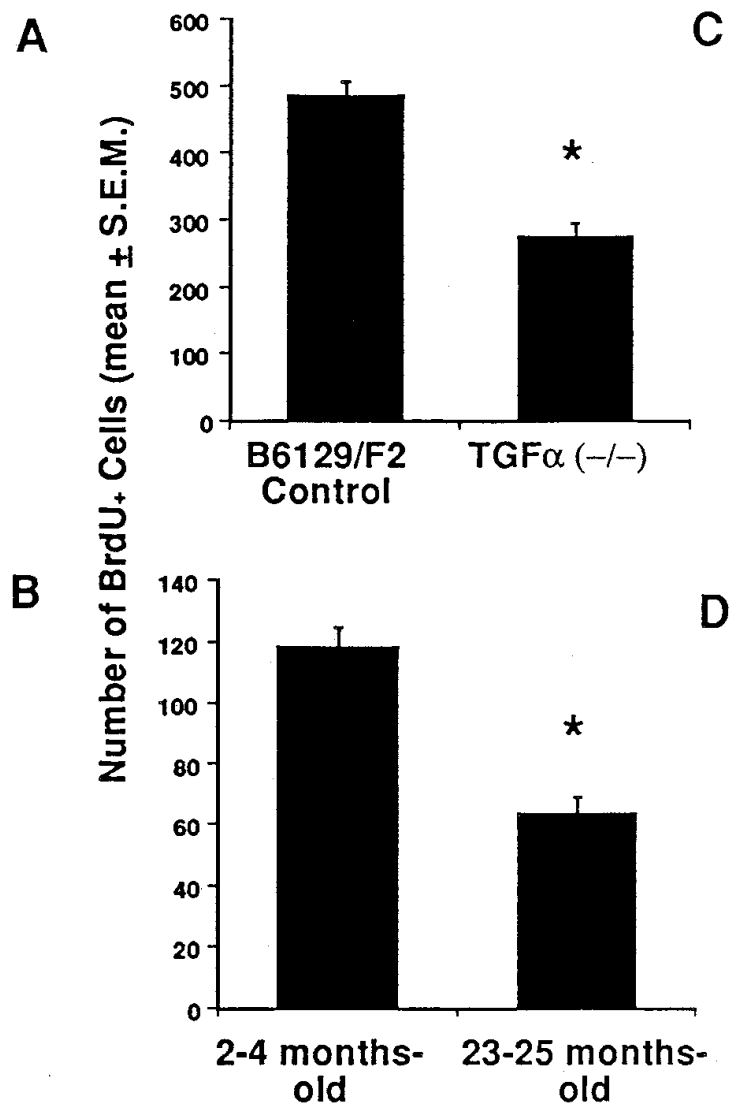

\author{
Remaining \\ Subependyma
}

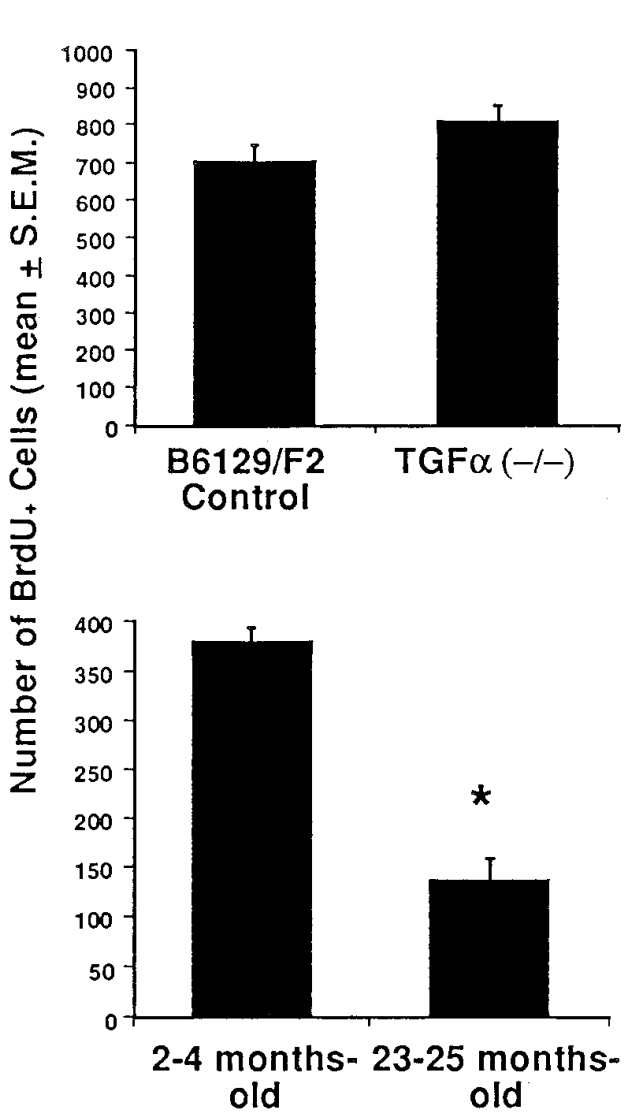

Figure 2. Attenuated proliferation in the forebrain subependyma of TGF $\alpha$-deficient and senescent mice. The number of proliferating $\left(B r d U^{+}\right)$cells were counted in the subependymal region of TGF $\alpha^{(-)}$and 23- to 25 -months-old mice. The mean ( \pm SEM) of the total number of BrdU ${ }^{+}$cells in the dorsolateral corner of the subependyma $(A, B)$ and the mean $( \pm \mathrm{SEM})$ of the total number of $\mathrm{BrdU}^{+}$cells throughout the nondorsolateral extent of the subependyma $(C, D)$ were estimated on the basis of counts between the rostral tip of the genu of the corpus callosum and the crossing of the anterior commissure from $(A, C)$ every seventh section in this region per animal, from young adult TGF $\alpha^{(-/-)}(n=4)$ mice and B6129/F2 $(n=4)$ controls, and from $(B, D)$ every seventh section in this region per animal, from 23 - to 25 -months-old $(n=5)$ mice and 2- to 4-months-old $(n=5)$ controls. * Significantly different from control $(p<0.05)$.

reduction in the numbers of neuronal progenitor cells that migrated to the olfactory bulb in the senescent mice compared with TGF $\alpha^{(-/-)}$mice $\left(t_{7}=3.62, p<0.05\right)$ indicates that the effects of senescence on this population are not caused exclusively by TGF $\alpha$ deficiency.

Interestingly, we observed a reduction in the numbers of constitutively proliferating progenitor cells in the dorsolateral corner of the subependyma and a maintenance of the numbers of constitutively proliferating progenitor cells throughout the remaining nondorsolateral subependyma in waved-1 homozygous mice as well (our unpublished observations). Furthermore, the numbers of neuronal progenitor cells that migrated to the olfactory bulbs from primarily the rostral, dorsolateral subependyma were diminished in these mice. Waved-1 is a TGF $\alpha$ hypomorphic mutation that is allelic with the $\mathrm{TGF} \alpha^{(-/-)}$mutation (Luetteke et al., 1993). Thus, these observations indicate that the proliferation of this cell population is very sensitive to the endogenous levels of TGF $\alpha$ because both the complete absence of TGF $\alpha$ (TGF $\alpha^{(-/-)}$ mice) and decreased levels of TGF $\alpha$ (waved-1 mice) significantly attenuate the proliferation of neural progenitor cells in the adult dorsolateral subependyma.
The labeling intensity of $\mathrm{BrdU}^{+}$cells in the olfactory bulb after a $31 \mathrm{~d}$ survival period was decreased compared with the labeling intensity of $\mathrm{BrdU}^{+}$cells in the subependyma after a 30 min survival period. A potential concern with long-term survival analyses is the dilution of the BrdU label in dividing cells; however, given that both the senescent and young adult control mice received identical labeling regimens, and because the cell cycle time in the senescent mice is increased compared with that in their young adult controls (see below), the decrease in the numbers of labeled cells in the olfactory bulb of senescent animals (compared with their controls) after $31 \mathrm{~d}$ cannot be caused by greater dilution of the label in the senescent mice. Indeed, the actual decrease in the olfactory bulb may be underestimated.

\section{Senescence causes a lengthening of the cell cycle in constitutively proliferating progenitor cells}

BrdU and ${ }^{3} \mathrm{H}$-thy double-labeling allowed assessment of whether a change in cell cycle time could account for the decrease in the number of constitutively proliferating progenitor cells in vivo in the senescent subependyma (which showed a larger overall decrease than the TGF $\alpha^{(-/-)}$subependyma). Mice were injected 

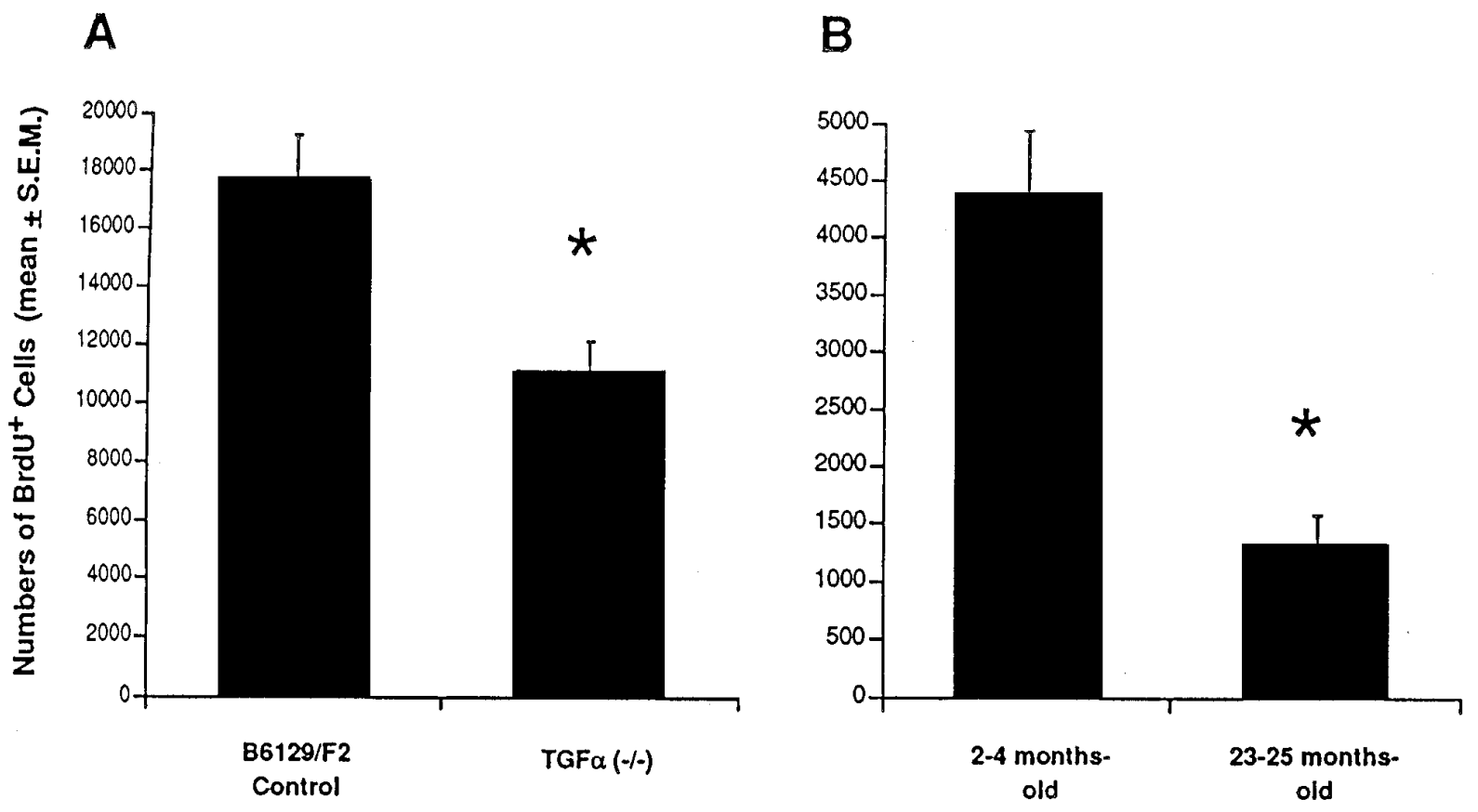

Figure 3. Numbers of $\mathrm{BrdU}^{+}$cells that migrated from the dorsolateral corner of the subependyma to the olfactory bulbs. The numbers of olfactory bulb $\mathrm{BrdU}^{+}$cells $31 \mathrm{~d}$ after BrdU injection in $(A) \mathrm{B} 6129 / \mathrm{F} 2$ control and TGF $\alpha^{(-/-)}$mice and $(B)$ 2- to 4-months-old control and 23- to 25-months-old mice. Counts are the mean \pm SEM of the total number of $\mathrm{BrdU}^{+}$cells (from every tenth section in this region per animal) from five separate mice in the $\mathrm{TGF} \alpha^{(-1-)}$ and control groups, and the total number of $\mathrm{BrdU}^{+}$cells (from every eighth section in this region per animal) from four separate mice in the senescent and control groups. * Significantly different from control $(p<0.05)$.

Figure 4. Estimate of change in cell cycle time in young adult and senescent mice. The average number $( \pm$ SEM) of cells doublelabeled as a percentage of total numbers of cells proliferating at $t=0$ were obtained from four hemisections from each of two 2to 4-months-old mice and two hemisections from each of three 23 - to 25 -months-old mice. * Significantly different from control $(p<0.05)$.

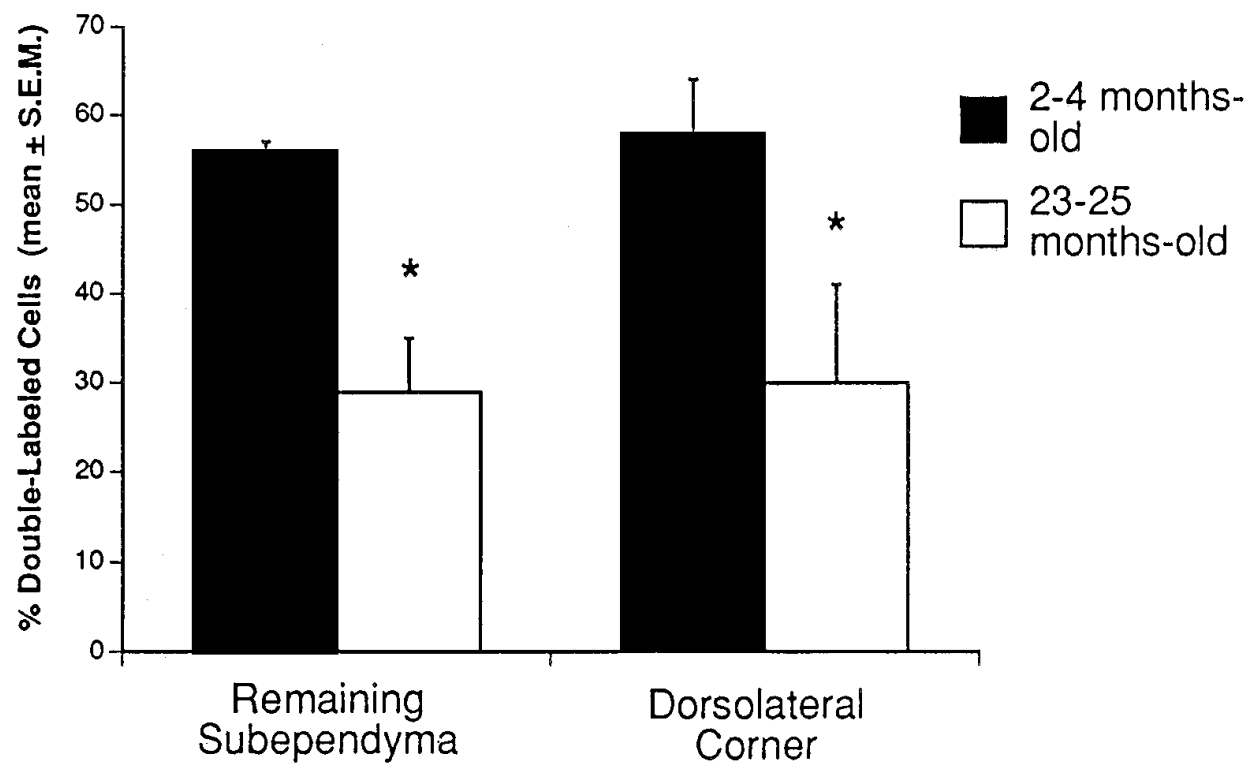

with a pulse of BrdU at time $t=0$ and a pulse of ${ }^{3} \mathrm{H}$-thy at $t=12.5$ $\mathrm{hr}$ to label subependymal cells in two consecutive S-phases of their cell cycles. Because the total cell cycle time for constitutively proliferating progenitor cells has been estimated as $\sim 12.5 \mathrm{hr}$ (Morshead and van der Kooy, 1992), only those cells that were originally labeled with $\mathrm{BrdU}$ at $t=0$ and that were reentering S-phase at the time of the ${ }^{3} \mathrm{H}$-thy pulse $(t=12.5)$ would incorporate the second marker into their DNA and thus become double-labeled.

In young adult mice (2-4 months old), $56 \%$ of the BrdUlabeled constitutively proliferating progenitor cells were double- labeled for ${ }^{3} \mathrm{H}$-thy around the nondorsolateral subependyma, and $58 \%$ were double-labeled in the dorsolateral corner of the subependyma (Fig. 4). These two percentages were not significantly different $\left(t_{2}=2.1 ; p>0.05\right)$ in the young adult mice, indicating that the cell cycle times of the constitutively proliferating progenitor cells are similar throughout the entire subependyma. Given that $40-45 \%$ of the cells that were proliferating at $t=0$ were not reentering S-phase at $t=12.5$ (not double-labeled), we suggest that roughly half of the progeny of the $\mathrm{BrdU}^{+}$cells adopted an alternative, nonproliferative fate. This steady-state mode of proliferation is required to maintain the size of the subependyma through- 
out adult life. Some of the neuronal progenitors in the dorsolateral corner become postmitotic and migrate rostrally to the olfactory bulbs (Lois and Alvarez-Buylla, 1993, 1994), and many of the postmitotic progeny of the constitutively proliferating progenitor cells undergo cell death (Morshead and van der Kooy, 1992).

In senescent mice (23-25 months old), only $30 \%$ of the dividing cells in the dorsolateral corner of the subependyma and throughout the remaining subependyma were still proliferating at $t=12.5$ (double-labeled with ${ }^{3} \mathrm{H}$-thy) (Fig. 4). This $30 \%$ rate in senescent mice is significantly less than the almost $60 \%$ double-labeled cells in the 2- to 4-months-old controls at $12.5 \mathrm{hr}\left(t_{4}=4.4 ; p<0.05\right)$. Again, no significant difference in the percentage of doublelabeled cells was observed between the dorsolateral corner and the rest of the subependymal region within the 23- to 25-monthsold group $\left(t_{4}=0 ; p>0.05\right)$. Thus, there is a $\sim 50 \%$ decrease in the relative numbers of constitutively proliferating progenitor cells dividing with a cell cycle time of $12.5 \mathrm{hr}$ in the subependyma of senescent mice compared with young adult controls. Given that, in addition to a change in cell cycle length, senescence produced a decrease in the numbers of proliferating cells labeled with continuous BrdU over $10 \mathrm{hr}$ and that the cell density is maintained in the subependyma (Nissl staining), the simplest interpretation of the data is that there is a longer average cell cycle time among the constitutively proliferating progenitor cells.

\section{Neural stem cell proliferation in vitro is unaltered in TGF $\alpha^{(-l-)}$ and senescent mice}

The decrease in the number of constitutively proliferating progenitor cells in the subependyma of $\mathrm{TGF}^{(-/-)}$and senescent mice could be a consequence of decreased proliferation by the neural stem cells, which are the lineage precursors to the progenitor cells (Morshead et al., 1994) and have been shown to proliferate in vitro to form clonal aggregates (neurospheres) in the presence of EGF (Reynolds and Weiss, 1992). In tissue culture preparations we observed no significant differences in the numbers of neurospheres clonally generated in EGF in vitro from neural stem cells in either TGF $\alpha^{(-/-)}\left(t_{4}=0.32 ; p>0.05\right)$ or senescent $\left(t_{4}=0.01 ; p>0.05\right)$ mice compared with their strainmatched controls (Fig. 5). Furthermore, the sizes of neurospheres generated in vitro did not change in $\mathrm{TGF} \alpha^{(-/-)}$or senescent mice compared with their controls (data not shown), suggesting that the progeny of stem cells in vitro seem to be capable of responding to a mitogenic signal through a normally functioning EGF receptor. It remains formally possible that the neural stem cells isolated from the $\mathrm{TGF} \alpha^{(-/-)}$mice have altered their responsiveness exclusively to TGF $\alpha$ and not to EGF, and that this prevents us from detecting an actual change in the neural stem cells in TGF $\alpha^{(-1-)}$ or senescent mice when they are assessed in vitro using EGF. However, the similarity between EGF and TGF $\alpha$ binding to the EGF-receptor (Massague, 1983; Marquardt et al., 1984) and the ability of both of these ligands to equally induce the proliferation of neural stem cells to generate neurospheres in vitro (Reynolds and Weiss, 1992) and to expand the subependymal precursor population in vivo (Craig et al., 1996) provide evidence suggesting that there is no functional distinction in the ability of these two ligands to induce neural stem cell proliferation.

We observed baseline differences attributable to mouse strain (B6, 129/F2 vs SW/COBS) in the numbers of neurospheres generated in both experimental (mutant vs old) groups and their appropriate controls. Strain differences also were observed in experiments assaying the numbers of constitutively proliferating progenitor cells in the dorsolateral corner and nondorsolateral

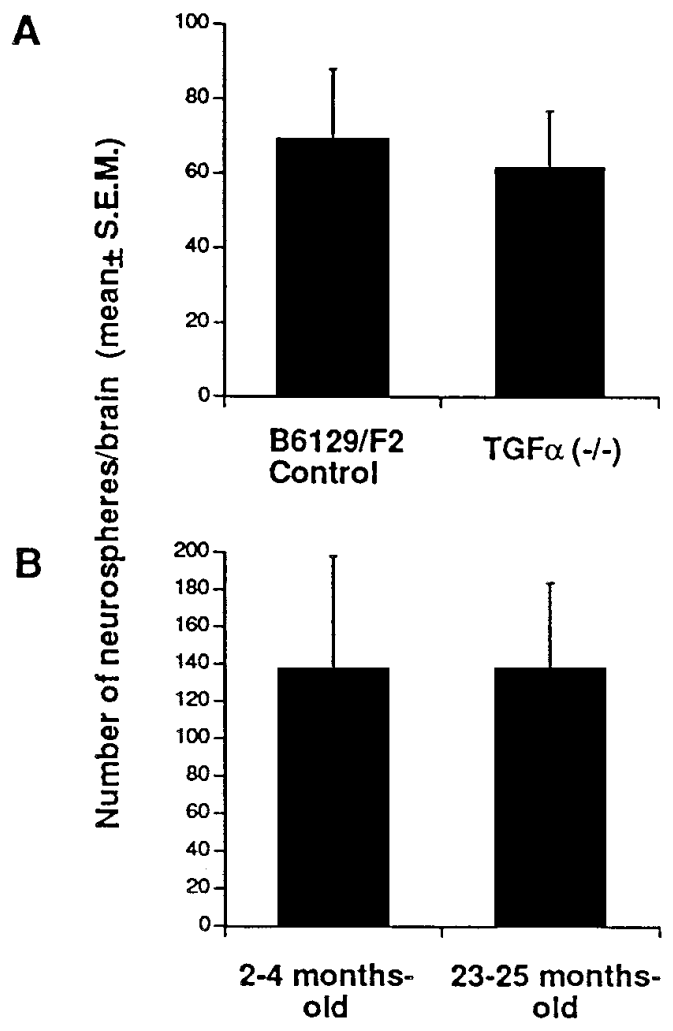

Figure 5. Clonal generation of neurospheres from subependymal neural stem cells in vitro is not affected in TGF $\alpha$-deficient and senescent mice. The number of neurospheres generated per brain from $(A)$ adult TGF $\alpha^{(-/-)}$mice and B6129/F2 controls and (B) 23- to 25-months-old and 2 - to 4-months-old controls after $12-14 \mathrm{~d}$ in vitro. Tissue from the medial and lateral (including the dorsolateral corner) aspects of the subependyma was dissected from both hemispheres, pooled together, and cultured in serum-free media in the presence of $20 \mathrm{ng} / \mathrm{ml} \mathrm{EGF}$. Data represent the mean \pm SEM for independent culture preparations from three mice in each group.

subependyma and the numbers of neuronal progenitors migrating to the olfactory bulb. The numbers of BrdU-labeled cells in the B6129/F2 strain were consistently greater than the numbers of BrdU-labeled cells in the SW/COBS strain across all experiments assaying the constitutively proliferating progenitor population. The opposite was true, however, for the analysis of the numbers of neural stem cells isolated in vitro between these two strains (more were isolated in the SW/COBS strain). These results suggest that distinct endogenous mechanisms can control the constitutively proliferating progenitor cell population and the neural stem cell population, and indeed that these two steps in the neural precursor lineage can be regulated independently.

\section{DISCUSSION}

\section{TGF $\alpha$ regulates the proliferation of a specific subpopulation of constitutively proliferating progenitor cells in the adult subependyma}

The results of the present study demonstrate that TGF $\alpha$ expression is required for the proliferation of constitutively proliferating progenitor cells localized to the dorsolateral corner of the adult subependyma but not the nondorsolateral subependyma. The proliferation of neuronal progenitor cells in the dorsolateral corner that migrate rostrally to the olfactory bulb (Lois and AlvarezBuylla, 1994) also is dependent on normal endogenous TGF $\alpha$ expression. Thus, the dorsolateral corner of the subependyma 


\section{A}

Rostral Dorsolateral corner of Subependyma:

Figure 6. Model representing the lineage relationships of neural stem cells and constitutively proliferating $(C P)$ progenitor cells. $A$, Neural stem cells localized to the dorsolateral corner of the adult forebrain subependyma give rise to $\mathrm{CP}$ progenitor cells that proliferate to give rise to neuronal progenitor cells that are destined to migrate to the olfactory bulbs where they differentiate into mature neurons. Some cells in the dorsolateral corner also may remain localized to the dorsolateral corner of the subependyma where they continue to proliferate and subsequently undergo cell death, as do the cells in the rest of the subependyma $(B) . B$, Neural stem cells throughout the rest of the subependyma give rise to $\mathrm{CP}$ progenitor cells that proliferate to give rise to one more $\mathrm{CP}$ cell and one cell destined to die. In both $A$ and $B$ the $\mathrm{CP}$ cells proliferate for $<1$ month before they are replenished by a neural stem cell division.

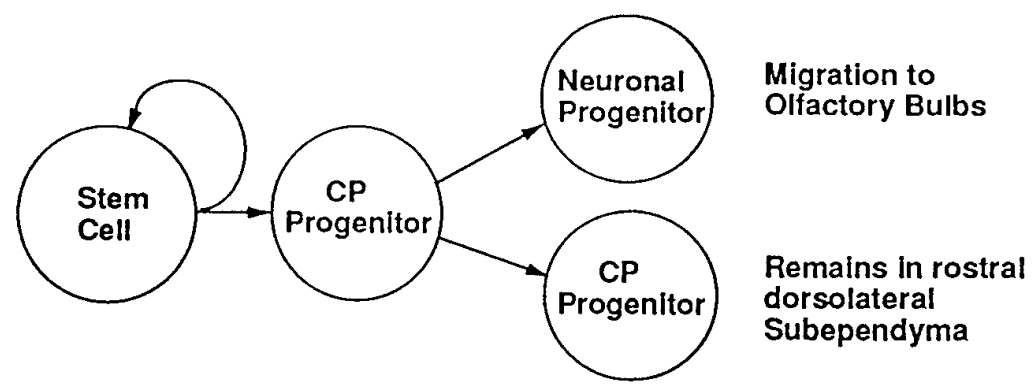

B The Rest of the Lateral Ventricle Subependyma:

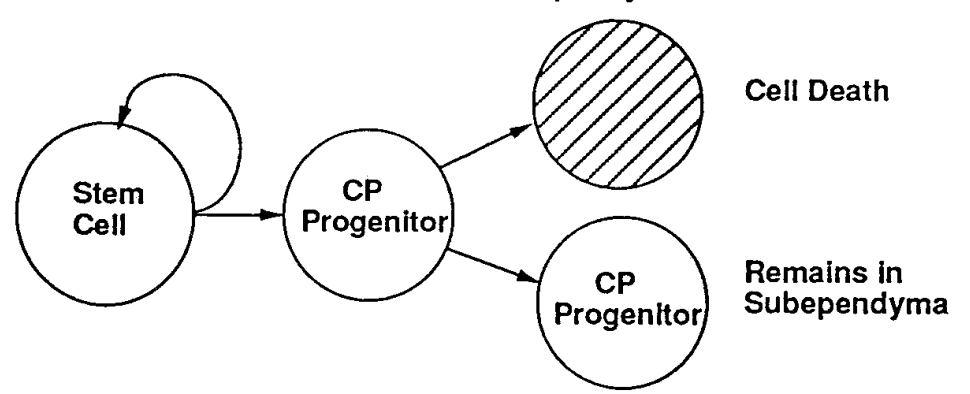

may contain most of the neuronal progenitors that migrate to the olfactory bulb. Perhaps the simplest hypothesis to explain the difference in TGF $\alpha$-dependent proliferation is that the same constitutively proliferating progenitor cell population responds differently depending on the growth factor expression in different regions of the adult subependyma (Fig. 6). TGF $\alpha$-dependent proliferation of constitutively proliferating progenitors may be contingent on their location in the dorsolateral corner. The relatively restricted domain of normal TGF $\alpha$ expression in rostral, dorsal regions of the forebrain (Wilcox and Derynck, 1988; Seroogy et al., 1993) may elicit a proliferative response only in those rostral, dorsolateral subependymal cells destined to migrate to the olfactory bulbs. The lack of a proliferation deficit in the constitutively proliferating progenitors throughout the remaining subependyma in the TGF $\alpha$ null mice suggests that other growth factors expressed in the nondorsolateral subependyma (ventrolateral and medial), especially EGF expression in more caudal and ventral regions such as the globus pallidus (Fallon et al., 1984; Seroogy et al., 1995), may regulate the proliferation of cells in this spatially distinct part of the forebrain subependyma.

It is unlikely that the TGF $\alpha$-dependent proliferation of cells only in the dorsolateral corner of the subependyma is indicative of an intrinsically distinct subpopulation of constitutively proliferating progenitor cells. First, intraventricular infusion of TGF $\alpha$ in the adult brain causes the proliferation and migration of constitutively proliferating progenitor cells throughout the entire subependymal region (Craig et al., 1996). Thus, progenitor cells localized to the ventrolateral and medial subependyma (along its entire rostral-caudal extent) that do not normally migrate into adjacent brain parenchyma in vivo can be induced to migrate with exogenous $\mathrm{TGF} \alpha$. Neural stem cells also proliferate in vivo in response to infused TGF $\alpha$ because the numbers of neurospheres subsequently isolated in the presence of EGF in vitro were augmented (Craig et al., 1996). Therefore, the expansion of the constitutively proliferating progenitor cell population in vivo is likely caused by the proliferation of both the progenitor and stem cell populations, which are capable of responding to EGFreceptor ligands. Second, heterotopic transplantation of progenitor cells originating at different rostrocaudal levels of the adult dorsolateral subependyma can migrate to the olfactory bulb and differentiate into neurons (Doetsch and Alvarez-Buylla, 1996), although in vivo the adult rostral dorsolateral corner of the subependyma may give rise to more olfactory bulb progenitors than the caudal dorsolateral corner (C. M. Morshead, C. G. Craig, and D. van der Kooy, unpublished observations). Finally, neuronal progenitor cells elsewhere in the adult brain can respond differentially to environment-specific cues. Adult rat hippocampal progenitor cells heterotopically transplanted to the rostral migratory pathway of olfactory bulb interneuron progenitors have been shown to migrate rostrally and to differentiate into neurons, some of which expressed tyrosine hydroxylase, an enzyme specific to olfactory bulb periglomerular dopaminergic neurons but not present in the hippocampus (Suhonen et al., 1996). The results of these studies and the present data describing the TGF $\alpha$ dependent proliferation of constitutively proliferating progenitor cells in the dorsolateral corner strongly support the hypothesis that there may be a single constitutively proliferating progenitor cell population, and that when members of this population are localized to the dorsolateral corner of the subependyma, they are then poised to divide in response to the relatively localized expression of TGF $\alpha$ to give rise to olfactory bulb neuronal progenitors.

The results also allow us to dissociate proliferation and migration with the dorsolateral constitutively proliferating population that gives rise to new adult olfactory bulb neurons. The olfactory bulb interneuron progenitor cells that are generated in the adult rostral, dorsolateral subependyma migrate along a distinct rostral migratory path to the olfactory bulb where they undergo differentiation (Lois and Alvarez-Buylla, 1994). Ultrastructural analyses demonstrate that the cells migrating from the lateral ventricle subependyma to the olfactory bulb (rostral migratory stream) are $\beta$-tubulin-positive and polysialic acid-neural cell adhesion mole- 
cule (PSA-NCAM)-positive neuroblasts (Type A cells) that are ensheathed by nonmigrating, GFAP-positive (Type B cells) astrocytes (Doetsch et al., 1997). Recent evidence suggests that the chained migration of neuronal progenitors on top of one another may be the mechanism by which the progeny of the constitutively proliferating progenitors migrate tangentially to the olfactory bulbs, and that PSA-NCAM is the critical factor that regulates the intercellular adhesion in this process (Tomasiewicz et al., 1993; Cremer et al., 1994; Rousselot et al., 1995; Hu et al., 1996; Lois et al., 1996). In the present study, the number of proliferating neuronal progenitors that migrated rostrally from the dorsolateral corner of the subependyma to the olfactory bulbs was diminished in the $\mathrm{TGF} \alpha^{(-)-)}$animals. This proliferation deficit seems to be a mechanistically and spatially distinct effect from the selective migratory deficit of neuronal progenitors to the olfactory bulbs in $\operatorname{NCAM}^{(-1-)}$ animals (Tomasiewicz et al., 1993; Cremer et al., 1994). Subependymal progenitor cells in the $\mathrm{NCAM}^{(-/-)}$mice accumulate in situ, causing an expansion of the subependymal zone, which suggests that proliferation of these progenitor cells is unaffected. Conversely, subependymal progenitor cells in the $\mathrm{TGF} \alpha^{(-/)}$mice show an intrinsic decrease in proliferation (a decrease in BrdU incorporation) with some preservation of cell migration, because the remaining progenitors in the dorsolateral corner give rise to cells that migrate from the subependyma to the olfactory bulb $31 \mathrm{~d}$ after BrdU administration. Furthermore, the apparently unaltered size of the olfactory bulbs of $\mathrm{TGF} \alpha^{(-/-)}$ animals suggests again that migration is spared and that the defect is selective in diminishing proliferation of constitutively proliferating progenitors within the subependyma. Thus, these data provide a clear distinction for the role of TGF $\alpha$ as a mitogen for constitutively proliferating progenitor proliferation versus the role of PSA-NCAM as a critical intercellular adhesion molecule for neuronal progenitor migration.

\section{Proliferation of constitutively proliferating progenitor cells in the subependyma is diminished in senescent mice}

The present study demonstrates that proliferation of constitutively proliferating progenitor cells is decreased in the dorsolateral corner and throughout the remaining subependyma by $\sim 50$ $60 \%$ in senescent compared with young adult mice. Furthermore, the number of neuronal progenitors that migrated to the olfactory bulbs is decreased by $\sim 70 \%$ in senescent mice. Thus, although proliferation of these progenitor cells persists in the adult mammalian subependyma, this proliferation diminishes with age. These results are consistent with previous studies demonstrating that in regions of the adult brain with persistent neurogenesis, such as the olfactory bulb and the dentate gyrus of the hippocampus, there is increased neuronal loss with age (Kaplan, 1985), and that proliferation in the subependyma diminishes with age (Hopewell, 1971). Although these studies reveal that the numbers of cells in these regions were decreased, evidence for diminished neurogenesis remained inconclusive (Kaplan, 1985). The diminished numbers of constitutively proliferating progenitor cells in the dorsolateral corner of the subependyma roughly correlates with the reduction in the numbers of neuronal progenitor cells that migrate to the olfactory bulb and therefore is consistent with the idea that neurogenesis in the forebrain subependyma is attenuated in senescent mice.

The similarity between the reductions of constitutively proliferating progenitor cell proliferation in the dorsolateral corner of the subependyma in TGF $\alpha$-deficient and senescent mice suggests that the same mechanism (decreased TGF $\alpha$ levels) may underlie the diminished proliferation in the dorsolateral corner in both groups of mice. It remains to be determined, however, whether the levels of TGF $\alpha$ expression in the senescent forebrain are decreased. Furthermore, decreased levels of TGF $\alpha$ in the senescent forebrain alone are insufficient to account for the greater reduction in the numbers of neuronal progenitor cells that migrated to the olfactory bulb in senescent mice when compared with the $\mathrm{TGF} \alpha^{(-/-)}$mice. This further supports the idea that proliferation of the constitutively proliferating progenitor cell lineage in the adult subependyma may be regulated by multiple, spatially distinct factors.

Recently, Kuhn et al. (1996) demonstrated that neurogenesis in the dentate gyrus of senescent rats also is diminished; however, in control experiments Kuhn et al. (1996) reported no change in the proliferation of subependymal progenitor cells in the senescent rat. It is possible that species differences (mouse vs rat), differences in the regions of the subependyma analyzed, and the lack of a stereological correction factor applied to their cell counts (40 $\mu \mathrm{m}$ thick sections) may have contributed to the discrepancy between studies. Nonetheless, our present results indicate that in the adult mouse forebrain subependyma, constitutively proliferating progenitor cells and committed neuronal progenitor cells have a limited proliferative potential in vivo.

Almost $60 \%$ of the constitutively proliferating progenitor cells in the 2- to 4-months-old control mice reentered S-phase after $12.5 \mathrm{hr}$ (the time of one cell cycle) and thus were double-labeled by $\mathrm{BrdU}$ and ${ }^{3} \mathrm{H}$-thy injections separated by $12.5 \mathrm{hr}$. One fate of the nondouble-labeled progeny (or at least a proportion of the remaining cells that are localized to the dorsolateral corner of the subependyma) may have been rostral migration to the olfactory bulb; however, the fate of most of the nondouble-labeled progeny of constitutively proliferating progenitor cells throughout the remaining subependyma (and indeed of some of the progeny in the rostral, dorsolateral corner as well) may have been cell death (Fig. 6). In senescent mice, the percentage of subependymal cells double-labeled at $t=12.5 \mathrm{hr}$ was $\sim 30 \%$ (down from $60 \%$ in the 2- to 4-months-old controls), indicating that there is a change in cell cycle time. Given that in addition to a change in cell cycle length senescence produced a decrease in the numbers of proliferating cells labeled with continuous BrdU over $10 \mathrm{hr}$ and yet the cell density was maintained in the subependyma, the simplest interpretation of the data is that there is a longer average cell cycle time among the constitutively proliferating progenitor cells in senescent mice. Assuming a steady-state mode of division, a longer cell cycle time, and a concurrent maintenance of cell density throughout the entire senescent subependyma, then cell death must be decreased (cells live longer) in proportion to the increase in cell cycle time. An alternative interpretation is that there is a shortening of the cell cycle and an increase in the amount of cell death. Although consistent with the observed change in the numbers of double-labeled cells and maintenance of cell density, this interpretation seems less likely, because under continuous BrdU-labeling conditions massive amounts of cell death in a very short period of time would be necessary to account for the observed reduction in the numbers of proliferating cells. Cumulative S-phase labeling or percentage labeled mitoses analyses of cell cycle time in the senescent mice and young adult control mice will be necessary to confirm that the estimated change in cell cycle truly reflects an increased cell cycle time. Whether this putative lengthening in cell cycle time is associated 
with changes in extrinsic growth factor regulation of cell division also remains to be determined.

\section{Neural stem cells are unaffected in TGF $\alpha^{(-/-)}$and senescent mice}

The ability of subependymal neural stem cells to proliferate in vitro in the presence of EGF is unaltered in $\mathrm{TGF} \alpha^{(-/-)}$and senescent mice. This is the first demonstration that the number of neural stem cells is maintained late in mammalian life. Thus, neural stem cells are present from the early stages (as early as E14) of neural development (Reynolds et al., 1992; Vescovi et al., $1993)$ to senescence (present results). This feature (long-term self-renewal) is a fundamental characteristic of stem cells (Potten and Loeffler, 1990; Weiss et al., 1996). The generation of a single neurosphere from the clonal proliferation of a single neural stem cell (Reynolds and Weiss, 1992, 1996) provided us with a quantitative assay for determining the numbers of neural stem cells that are capable of proliferating in response to EGF in vitro. The unaltered ability of adult neural stem cells from $\mathrm{TGF} \alpha^{(-)-)}$mice to generate neurospheres in vitro also suggests that other growth factors, such as EGF or basic fibroblast growth factor, can regulate neural stem cell proliferation during in vivo development. Indeed, stem cells do not depend on the endogenous expression of TGF $\alpha$ during development, because the capacity of neural stem cells to respond to EGF (the defining member of the EGF-receptor ligand family) is conserved in $\mathrm{TGF} \alpha^{(-/-)}$mice.

\section{Summary}

This study demonstrates that in the rostral, dorsolateral corner of the adult forebrain subependyma, TGF $\alpha$ is necessary for regulating the proliferation of constitutively proliferating progenitors that give rise to neuronal progenitors migrating to the olfactory bulbs. We propose that the constitutively proliferating progenitor cells throughout the forebrain subependyma are capable of proliferating in response to different endogenous growth factors (e.g., EGF-receptor signaling ligands) that are localized in spatially distinct domains, and that the neural stem cell (also responsive to EGF-receptor ligands) is the lineage precursor to the entire constitutively proliferating progenitor population (Fig. 6). The survival and proliferation of the forebrain neural stem cell itself does not depend on TGF $\alpha$ signaling specifically, and these neural stem cells remain undiminished in the adult forebrain subependyma throughout life, even in senescent animals. The postmitotic progeny of constitutively proliferating progenitors throughout the nondorsolateral forebrain subependyma (and indeed of some in the dorsolateral corner as well) that do not respond to the endogenous TGF $\alpha$ signal undergo cell death and thus maintain a steady-state mode of division with no expansion of the overall subependymal population itself. The diminished proliferation of constitutively proliferating progenitor cells throughout the subependyma in senescent mice likely reflects a lengthening in the cell cycle time and may be a consequence of age-related changes in the mechanisms that regulate the proliferation of this cell population throughout the adult forebrain.

\section{REFERENCES}

Abercrombie M (1946) Estimation of nuclear populations from microtome sections. Anat Rec 94:239-247.

Altman J (1969) Autoradiographic and histological studies of postnatal neurogenesis. IV. Cell proliferation and migration in the anterior forebrain, with special reference to persisting neurogenesis in the olfactory bulb. J Comp Neurol 137:433-457.

Coggeshall RE, Lekan HA (1996) Methods for discriminating numbers of cells and synapses: a case for more uniform standards of review. J Comp Neurol 364:6-15.

Craig CG, Tropepe V, Morshead CM, Reynolds BA, Weiss S, van der Kooy D (1996) In vivo growth factor expansion of endogenous subependymal neural precursor cell populations in the adult mouse brain. J Neurosci 16:2649-2658.

Cremer H, Lange R, Christoph A, Plomann M, Vopper G, Roes J, Brown R, Baldwin S, Kraemer P, Scheff S, Barthels D, Rajewsky K, Wille W (1994) Inactivation of the $\mathrm{N}$-cam gene in mice results in size reduction of the olfactory bulb and deficits in spatial learning. Nature 367:455-459.

Davis AA, Temple S (1994) A self-renewing multipotential stem cell in embryonic rat cerebral cortex. Nature 372:263-266.

Doetsch F, Alvarez-Buylla A (1996) Network of tangential pathways for neuronal migration in adult mammalian brain. Proc Natl Acad Sci USA 93:14895-14900.

Doetsch F, Garcia-Verdugo JM, Alvarez-Buylla A (1997) Cellular composition and three-dimensional organization of the subventricular germinal zone in the adult mammalian brain. J Neurosci 17:5046-5061.

Fallon JH, Seroogy KB, Loughlin SE, Morrison RS, Bradshaw RA, Knauer DJ, Cunningham DD (1984) Epidermal growth factor immunoreactive material in the central nervous system: location and development. Science 224:1107-1109.

Gritti A, Parati EA, Cova L, Frolichsthal P, Galli R, Wanke E, Faravelli L, Morassutti DJ, Roisen F, Nickel DD, Vescovi AL (1996) Multipotential stem cells from the adult mouse brain proliferate and self-renew in response to basic fibroblast growth factor. J Neurosci 16:1091-1100.

Hopewell JW (1971) A quantitative study of the mitotic activity in the subependymal plate of adult rats. Cell Tissue Kinet 4:273-278.

$\mathrm{Hu} \mathrm{H}$, Tomasiewicz H, Magnuson T, Rutishauser U (1996) The role of polysialic acid in migration of olfactory bulb interneuron precursors in the subventricular zone. Neuron 16:735-743.

Kaplan MS (1985) Formation and turnover of neurons in young and senescent animals: an electronmicroscopic and morphometric analysis. Ann NY Acad Sci 457:173-192.

Kuhn HG, Dickinson-Anson H, Gage FH (1996) Neurogenesis in the dentate gyrus of the adult rat: age-related decrease of neuronal progenitor proliferation. J Neurosci 16:2027-2033.

Lois C, Alvarez-Buylla A (1993) Proliferating subventricular zone cells in the adult mammalian forebrain can differentiate into neurons and glia. Proc Natl Acad Sci USA 90:2074-2077.

Lois C, Alvarez-Buylla A (1994) Long-distance neuronal migration in the adult mammalian brain. Science 264:1145-1148.

Lois C, Garcia-Verdungo J-M, Alvarez-Buylla A (1996) Chain migration of neuronal precursors. Science 271:978-981.

Luetteke NC, Qiu TH, Pfeiffer RL, Oliver P, Smithies O, Lee DC (1993) TGF- $\alpha$ deficiency results in hair follicle and eye abnormalities in targeted and waved-1 mice. Cell 73:263-276.

Luskin MB (1993) Restricted proliferation and migration of postnatally generated neurons derived from forebrain subventricular zone. Neuron 11:173-189.

Mann GB, Fowler KJ, Grabriel A, Nice EC, Williams RL, Dunn A (1993) Mice with a null mutation of the tgf- $\alpha$ gene have abnormal skin architecture, wavy hair and curly whiskers and often develop corneal inflammation. Cell 73:249-261.

Marquardt H, Hunkapiller MW, Hood LE, Todaro GJ (1984) Rat transforming growth factor type-1: structure and relation to epidermal growth factor. Science 223:1079-1082.

Massague J (1983) Epidermal growth factor-like transforming growth factor. II. Interaction with epidermal growth factor receptors in human placenta membranes and A431 cells. J Biol Chem 258:13614-13620.

Morshead CM, van der Kooy D (1992) Postmitotic death is the fate of constitutively proliferating cells in the subependymal layer of the adult mouse brain. J Neurosci 12:249-256.

Morshead CM, Reynolds BA, Craig CG, McBurney MW, Staines WA, Morassutti D, Weiss S, van der Kooy D (1994) Neural stem cells in the adult mammalian forebrain: a relatively quiescent subpopulation of subependymal cells. Neuron 13:1071-1082.

Nowakowski RS, Lewin SB, Miller MW (1989) Bromodeoxyuridine immunohistochemical determination of the lengths of the cell cycle and the DNA-synthetic phase for an anatomically defined population. J Neurocytol 18:311-318.

Potten CS, Loeffler M (1990) Stem cells: attributes, cycles, spirals, pitfalls and uncertainties. Lessons for and from the crypt. Development 110:1001-1020. 
Privat A, Leblond CP (1972) The subependymal layer and neighboring region in the brain of the young rat. J Comp Neurol 146:277-302.

Reynolds BA, Weiss S (1992) Generation of neurons and astrocytes from isolated cells of the adult mammalian central nervous system. Science 255:1707-1710.

Reynolds BA, Weiss S (1996) Clonal and population analyses demonstrate that an EGF-responsive mammalian embryonic CNS precursor is a stem cell. Dev Biol 175:1-13.

Reynolds BA, Tetzlaff W, Weiss S (1992) A multipotent EGFresponsive striatal embryonic progenitor cell produces neurons and astrocytes. J Neurosci 12:4565-4574.

Rousselot P, Lois C, Alvarez-Buylla A (1995) Embryonic (PSA) N-CAM reveals chains of migrating neuroblasts between the lateral ventricle and the olfactory bulb of adult mice. J Comp Neurol 351:51-61.

Seroogy KB, Lundgren KH, Lee DC, Guthrie KM, Gall CM (1993) Cellular localization of transforming growth factor- $\alpha$ mRNA in rat forebrain. J Neurochem 60:1777-1782.

Seroogy KB, Numan S, Gall CM, Lee DC, Kornblum HI (1994) Expression of EGF receptor mRNA in rat nigrostriatal system. NeuroReport 6:105-108.

Seroogy KB, Gall CM, Lee DC, Kornblum HI (1995) Proliferative zones of postnatal rat brain express epidermal growth factor receptor mRNA. Brain Res 670:157-164.

Suhonen JO, Peterson DA, Ray J, Gage FH (1996) Differentiation of adult hippocampus-derived progenitors into olfactory neurons in vivo. Nature 383:624-627.

Takahashi T, Nowakowski RS, Caviness Jr VS (1996a) Interkinetic and migratory behavior of a cohort of neocortical neurons arising in the early embryonic murine cerebral wall. J Neurosci 16:5762-5776.

Takahashi T, Nowakowski RS, Caviness Jr VS (1996b) The leaving or Q fraction of the murine cerebral proliferative epithelium: a general model of neocortical neuronogenesis. J Neurosci 16:6183-6196.

Tomasiewicz H, Ono K, Yee D, Thompson C, Goridis C, Rutishauser U, Magnuson T (1993) Genetic deletion of a neural cell adhesion molecule variant (N-CAM-180) produces distinct defects in the central nervous system. Neuron 11:1163-1174.

Vescovi AL, Reynolds BA, Fraser DD, Weiss S (1993) bFGF regulates the proliferative fate of unipotent (neuronal) and bipotent (neuronal/astroglial) EGF-generated CNS progenitor cells. Neuron 11:951-966.

Weiss S, Reynolds BA, Vescovi AL, Morshead C, Craig CG, van der Kooy D (1996) Is there a neural stem cell in the mammalian forebrain? Trends Neurosci 19:387-393.

Wilcox JN, Derynck R (1988) Localization of cells synthesizing transforming growth factor-alpha mRNA in the mouse brain. J Neurosci 8:1901-1904.

Zamboni L, de Martino C (1967) Buffered acid formaldehyde: a new rapid fixative for electron microscopy. J Cell Biol 148A:35-41. 